\title{
Pembuatan Alat Bantu Cuci Tangan Menggunakan Teknologi Sederhana SD Swasta HKBP II Pajak Baru Belawan
}

\author{
Martha Rianna ${ }^{1 *}$, Friska Febriana ${ }^{2}$, Perdinan Sinuhaji ${ }^{3}$, \\ Noverita Sprinse Vinolina ${ }^{4}$, Muhammadin Hamid $^{5}$ \\ ${ }^{1345}$ Universitas Sumatera Utara, Medan, 20155, Indonesia \\ ${ }^{2}$ Sekolah Tinggi Ilmu Farmasi Riau, Pekanbaru, 28289, Indonesia \\ Author E-mail: martharianna@usu.ac.id
}

\begin{abstract}
A B S T R A K
Pandemi Covid-19 telah melanda dunia khususnya Indonesia sehingga berdampak dalam kebiasaan sehari-hari. Begitu juga berdampak pada aktivitas belajar mengajar di lingkungan sekolah khususnya di SD Swasta HKBP Pajak Baru Belawan. Metode yang digunakan dalam pengabdian ini adalah pembuatan alat cuci tangan menggunakan teknologi sederhana dan mendemonstrasikan penggunaan alat cuci tangan dengan menggunakan teknologi sederhana yaitu pedal kaki serta membangun 6 kran air untuk menambah fasilitas tempat mencuci tangan bersama siswa dan guru. Melalui pengabdian masyarakat ini telah dibuat alat pencuci tangan menggunakan teknologi sederhana serta sosialisasi mengenai penerapan Protokol Kesehatan yang ditetapkan Pemerintah. Alat pencuci tangan dari pedal kaki ini diharapkan membantu meningkatkan tingkat efektivitas dan mempersingkat waktu yang dibutuhkan untuk mencuci tangan. Perkembangan teknologi dibutuhkan hampir di seluruh area kehidupan manusia khususnya di lingkungan SD HKBP Pajak Baru Belawan. Pengabdian masyarakat ini diharapkan dapat membuat dan merancang alat pencuci tangan dari mekanisme pedal kaki yang dapat membantu seluruh siswa dan guru untuk menghemat waktu dan air sehingga memperlancar proses belajar mengajar di tengah pandemi Covid-19. Alat cuci tangan menggunakan pedal kaki dan ditambah dengan 6 kran air telah berfungsi dengan baik. Alat cuci tangan ini menggunakan pedal kaki dan rangkaian kran air mengeluarkan air dengan lancar dan sudah dipergunakan oleh guru dan siswa di SD Swasta HKBP II Pajak Baru Belawan dalam melakukan aktivitas belajar mengajar.
\end{abstract}

Kata Kunci: Alat Cuci Tangan Pedal Kaki, SD Swasta HKBP II Pajak Baru Belawan, Covid-19.

\section{A B S T R A C T}

The Covid-19 pandemic has hit the world, especially Indonesia, so that it has an impact on daily habits. Likewise, it has an impact on teaching and learning activities in the school environment, especially in the HKBP Pajak Baru Belawan Private Elementary School. The method used in this service is making 
hand washing tools using simple technology and demonstrating the use of hand washing tools using simple technology, namely foot pedals and building 6 water faucets to add facilities for washing hands with students and teachers. Through this community service, hand washing tools will be made using simple technology and socialization regarding the implementation of the Health Protocol set by the Government was conducted. The hand washing device from the foot pedal is expected to help to increase the level of effectiveness and to shorten the time needed to wash the hands. Technological developments are needed in almost all areas of human life, especially in the SD HKBP Baru Belawan environment. This community service is expected to be able to create and design hand washing tools from the foot pedal mechanism that can help all students and teachers to save time and water so as to facilitate the teaching and learning process in Covid-19. The hand washing tool using the foot pedal and the 6 water faucets works well. The hand washing device uses a foot pedal and a series of water faucets to release water smoothly and has been used by teachers and students at the HKBP II Pajak Baru Belawan Private Elementary School to facilitate the teaching and learning activities.

Keywords: Hand Washing Tool, SD Swasta HKBP II Pajak Baru Belawan, Covid-19.

\section{PENDAHULUAN}

Indonesia dan dunia sedang dilanda virus covid-19 dalam dua tahun belakangan ini. Virus ini dapat menular lebih cepat melalui percikan hidung maupun mulut dari seseorang kepada yang lain di sekitarnya. Seseorang mudah menularkan virus ini apabila tidak taat pada protokol kesehatan. Oleh sebab itu, untuk mengurangi resiko terinfeksi atau memutus rantai Covid-19 dapat dilakukan dengan cara berikut, memakai selalu masker kemanapun kita berada, menjaga jarak, dan rajin mencuci tangan dengan air bersih mengalir menggunakan sabun sehingga tangan akan menjadi selalu bersih (Kristyawati and Nurcahyo 2015).

Kegiatan mencuci tangan sangat penting dilakukan untuk menjaga kebersihan jasmani agar terhindar dari penyakit virus ataupun bakteri (Arsianti et al. 2020). Kebiasaan mencuci tangan sebelum makan selalu kita lakukan, namun dalam pandemi ini kita harus rajin mencuci tangan setiap melakukan aktivitas di lingkungan sehari-hari. Rekomendasi WHO, cuci tangan yang efektif dilakukan 20 detik hingga 30 detik (Allegranzi and Pittet 2009).

Pandemi Covid-19 berdampak pada kebiasaan dalam melakukan aktivitas sehari-hari terutama juga dalam aktivitas belajar mengajar di lingkungan sekolah. Aktivitas belajar mengajar di masa pandemi saat ini menerapkan protokol kesehatan yang ketat yang mengacu pada ketetapan Pemerintah dimana salah satunya adalah mencuci tangan. Melalui pengabdian masyarakat ini akan dibuat alat pencuci tangan menggunakan teknologi sederhana serta sosialisasi mengenai penerapan Protokol Kesehatan yang ditetapkan Pemerintah. Alat pencuci tangan dari pedal kaki ini diharapkan membantu meningkatkan efektivitas dan mempersingkat waktu yang dibutuhkan untuk mencuci tangan. Perkembangan teknologi dibutuhkan hampir di seluruh area kehidupan manusia khususnya di lingkungan SD HKBP Pajak Baru Belawan, Sumatera Utara.

Permasalahan mitra di SD Swasta HKBP II Pajak Baru Belawan ini adalah fasilitas alat cuci tangan yang masih manual dengan mengangkat air dari toilet dan dimasukkan ke ember sebagai sumber air sehingga mengakibatkan antrian yang panjang dan tangan siswa yang menyentuh kran air serta sebagian siswa mencuci tangan di toilet sekolah sehingga berdampak pada kemungkinan penyebaran virus Covid-19 karena 
siswa saling menyentuh benda yang sama yaitu kran air, sementara jumlah siswa cukup banyak yaitu 154 orang. Aktivitas ini juga berdampak pada waktu yang terpakai lebih lama sehingga menganggu jam belajar mengajar seluruh siswa dan guru di SD Swasta HKBP II Pajak Baru Belawan. Pengabdian masyarakat ini diharapkan dapat membuat dan merancang alat pencuci tangan dari mekanisme pedal kaki yang dapat membantu seluruh siswa dan guru untuk menghemat waktu dan air sehingga memperlancar proses belajar mengajar di tengah pandemi Covid-19.

\section{METODE PELAKSANAAN PKM}

Metode pendekatan yang dilakukan selama melakukan pengabdian kepada mitra adalah melakukan penyuluhan mengenai sosialisasi protokol kesehatan yang ditetapkan Pemerintah dalam menjalankan aktivitas belajar-mengajar di lingkungan sekolah dan demonstrasi penggunaan alat bantu cuci tangan dengan menggunakan teknologi sederhana yaitu pedal kaki serta membangun 6 kran air untuk menambah fasilitas tempat mencuci tangan. Beberapa pendekatan yang dapat dilakukan secara bertahap dalam rangka mensukseskan pengabdian kepada masyarakat ini adalah pertama melalui pembuatan alat bantu cuci tangan dengan menggunakan teknologi sederhana, ke dua, memberikan penyuluhan menjaga kebersihan lingkungan dalam upaya menjaga kebersihan sekolah pada lingkungan sekolah SD Swasta HKBP II Pajak Baru Belawan untuk mencegah penyebaran virus Covid 19 dan ke tiga melalui demonstrasi penggunaan alat bantu cuci tangan dengan teknologi sederhana kepada siswa dan guru di SD Swasta HKBP II Pajak Baru Belawan. Langkah ke empat adalah melakukan evaluasi lapangan untuk menganalisa dan merencanakan keberlanjutan program.

\section{HASIL DAN PEMBAHASAN}

Kegiatan Program Pengabdian kepada Masyarakat ini dimulai dari Juni sampai dengan Agustus 2021 dengan tahapan kegiatan seperti yang tertera pada metodologi pelaksanaan. Gambar kegiatan berikut merupakan dokumentasi kegiatan pengabdian kepada masyarakat saat proses kegiatan pembuatan alat dan pembangunan kran cuci tangan.

Gambar 1 merupakan alat pencuci tangan menggunakan teknologi sederhana (pedal kaki) dan rangkaian 6 kran air untuk mencuci tangan. Kedua alat tersebut dapat digunakan dengan baik, dan aliran air mengalir dengan lancar.

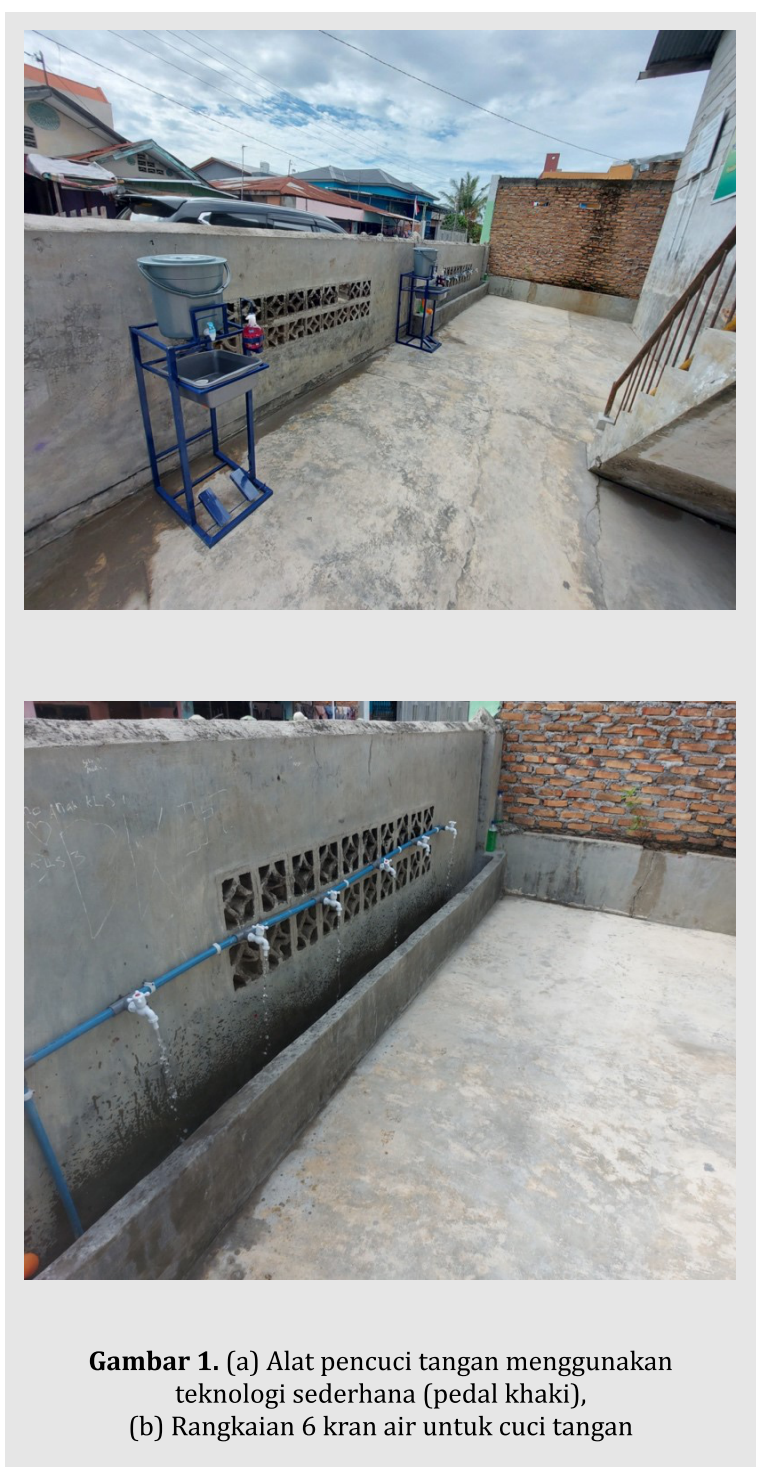

Gambar 2 merupakan kondisi pengujian alat pencuci tangan menggunakan teknologi sederhana (pedal kaki) dan rangkaian 6 kran air untuk cuci tangan di lokasi mitra pengabdian. Dalam proses pengujian tim dibantu oleh masyarakat dalam merangkai alat pencuci tangan 
menggunakan teknologi sederhana (pedal kaki) dan pembangunan kran air cuci tangan di SD Swasta HKBP II Pajak Baru, Belawan. Hasilnya teruji dalam keadaan baik dan alat sudah dapat dipergunakan oleh siswa dan guru. Setelah melakukan pengujian untuk kedua alat tersebut, kegiatan pengabdian dilanjutkan dengan memberikan penyuluhan tentang kebersihan dengan cara mencuci tangan dan pentingnya melakukan protokol kesehatan di masa pandemi Covid-19.

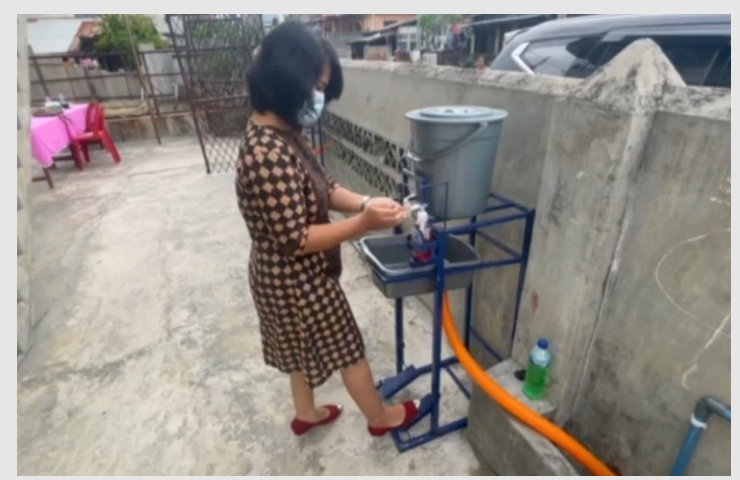

(a)

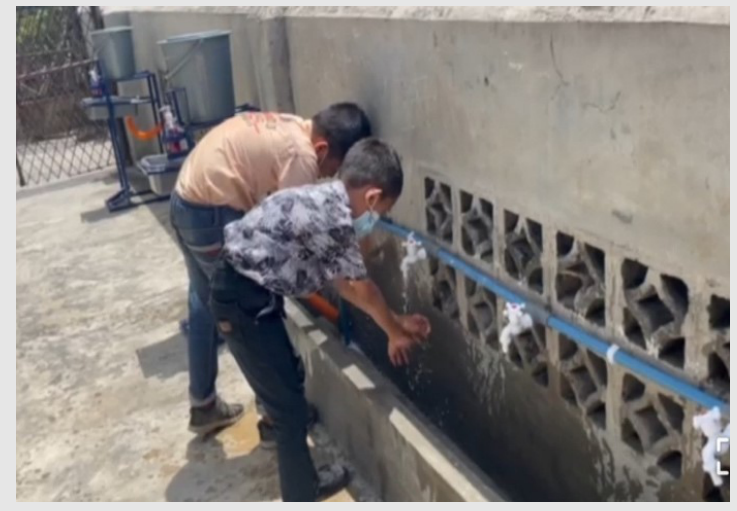

(b)

Gambar 2. (a) Kegiatan pengujian alat pencuci tangan menggunakan teknologi sederhana (pedal kaki)

(b) Kegiatan pengujian rangkaian 6 kran air untuk cuci tangan

Gambar 3 dan Gambar 4 menunjukkan dokumentasi sosialisasi tentang protokol kesehatan dan memberikan motivasi untuk siswa dan guru di SD Swasta II HKBP Pajak Baru Belawan oleh tim pengabdi dari Universitas Sumatera Utara. Selain itu, tim pengabdi juga memberikan motivasi kepada siswa-siswa dalam menggapai prestasi dan meraih cita-cita.

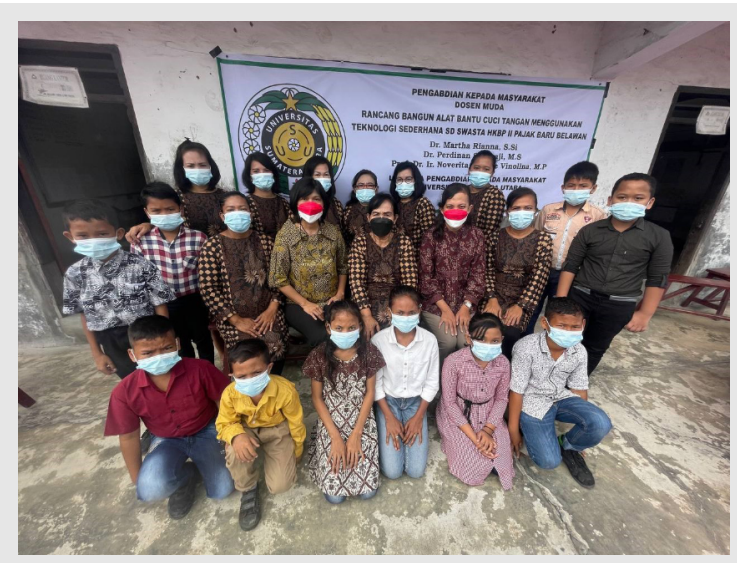

Figure 3. Sosialisasi tentang protokol kesehatan dan memberikan motivasi untuk siswa dan guru
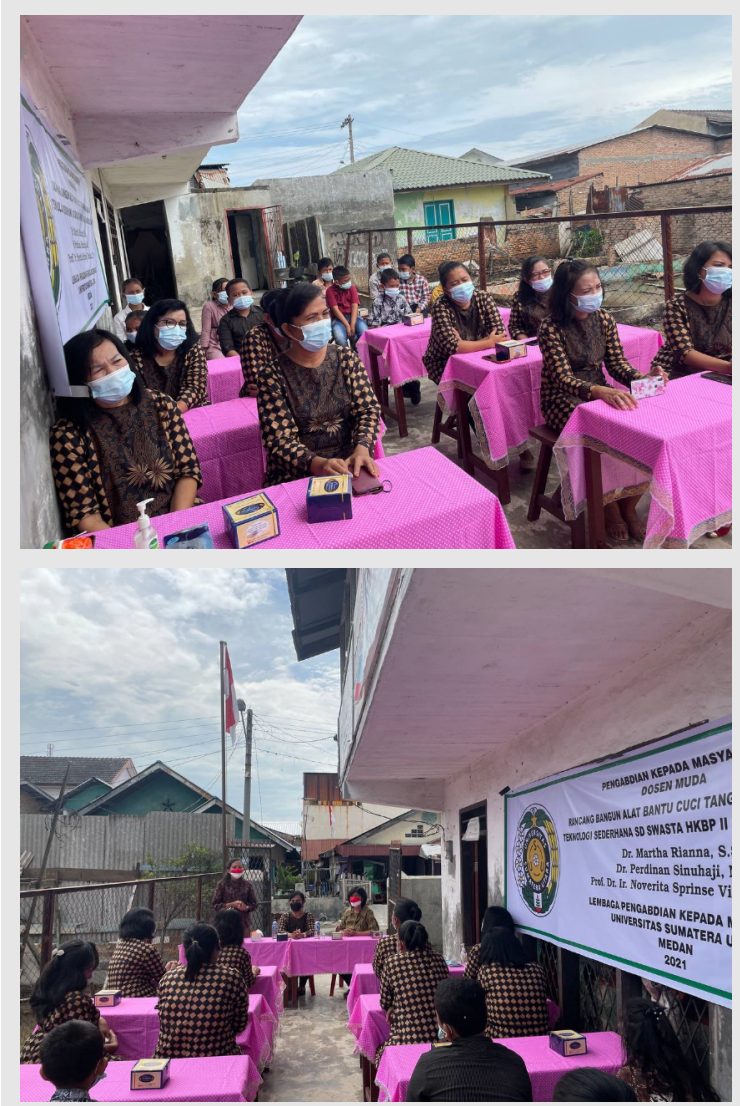

Gambar 4. Tim Pengabdi Universitas Sumatera Utara memberikan sosialisasi program kerja pengabdian dan motivasi untuk para guru dan siswa SD Swasta HKBP II Pajak Baru Belawan

Pemberian motivasi dari tim pengabdi memberikan dampak baik terhadap siswa dan guru di lingkungan sekolah tersebut. Hal ini ditunjukkan dari respon oleh siswa dan guru di SD Swasta HKBP II Pajak Baru Belawan. Sekolah SD Swasta HKBP II Pajak Baru Belawan ini beralamat di Jln. Terubuk No. 17 Belawan Bahagia 
dengan Nomor Data Sekolah : G17101001 dan Yayasan / Penyelenggara : Yayasan HKBP Pajak Baru Belawan. Sekolah ini memiliki staf pengajar 7 orang, jumlah tata usaha 1 orang dan jumlah siswa 154 orang. Kepala Sekolah SD Swasta HKBP II Pajak Baru Belawan, Nurhaida Simatupang, S.Pd menyampaikan bahwa sekolah SD Swasta HKBP II Pajak Baru Belawan telah berdiri sejak tanggal 10 Maret 1990 atau sekitar 31 tahun yang lalu. Ibu Nurhaida Simatupang, S.Pd juga menuturkan bahwa sekolah ini sebenarnya sudah berdiri sejak tahun 1971. Pada waktu tersebut sekolah ini masih bersatu dengan HKBP Jln. Kampar dan pada tanggal 10 Maret 1990, sekolah ini berdiri sendiri sehingga keluar akte sekolah pada tanggal 10 Maret 1990. Namun gedung sekolah ini masih terbuat dari papan dan kondisi kelas sangat memprihatinkan.

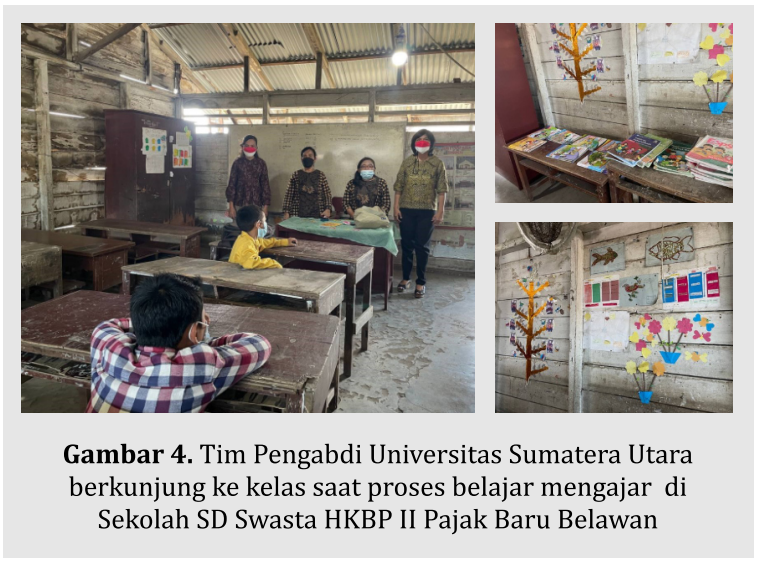

Gedung sekolah ini selalu terkena pasang setiap hari sehingga siswa sering dipulangkan duluan akibat seluruh ruangan kelas tergenang air pasang. Ruangan kelas terkesan seadanya dengan tidak ada asbes dan plafon yang menyertainya. Harapan dari Ibu Nurhaida Simatupang, S.Pd selaku Kepala Sekolah SD Swasta HKBP II Pajak Baru Belawan adalah kiranya sekolah ini dapat diberikan kesempatan dalam mendapatkan bantuan perbaikan gedung dan fasilitas sarana prasarana dari Pemerintah sehingga gedung sekolah menjadi lebih layak dan membuat nyaman bagi guru dan siswa dalam melakukan proses belajar mengajar. Bila mendapatkan dukungan sarana dan prasarana yang layak, sekolah dapat mencetak SDM generasi muda dengan cara yang lebih baik agar dapat menjadi cerdas dan maju untuk Indonesia yang lebih jaya.

\section{KESIMPULAN}

Alat pencuci tangan menggunakan teknologi pedal kaki sederhana, pembuatan 6 kran cuci tangan, sosialisasi tentang protokol kesehatan dan pemberian motivasi kepada siswa dan guru telah berjalan dengan baik. Hasil pembuatan alat pencuci tangan dari pedal kaki ini dapat membantu meningkatkan tingkat efektivitas dan mempersingkat waktu yang dibutuhkan terutama di lingkungan SD HKBP Pajak Baru Belawan. Pengabdian masyarakat ini dapat membantu sekolah dalam membuat dan merancang alat pencuci tangan dari mekanisme pedal kaki. Alat ini telah dapat membantu seluruh siswa dan guru untuk menghemat waktu dan air sehingga memperlancar proses belajar mengajar di tengah pandemi Covid-19. Alat cuci tangan menggunakan pedal kaki dan ditambah dengan 6 kran air telah berhasil digunakan dan berfungsi dengan baik. Alat cuci tangan menggunakan pedal kaki dan rangkaian kran air mengeluarkan air dengan lancar dan sudah dipergunakan oleh guru dan siswa di SD Swasta HKBP II Pajak Baru Belawan sehingga memudahkan siswa dan guru dalam melakukan aktivitas belajar mengajar.

\section{UCAPAN TERIMA KASIH}

Penulis mengucapkan terima kasih kepada Universitas Sumatera Utara dalam memfasilitasi kegiatan pengabdian masyarakat di SD Swasta HKBP II Pajak Baru Belawan melalui skim Kemitraan Mono Tahun Dosen Muda No. 185 / UN5.2.3.2.1 / PPM / 2021. Penulis juga mengucapkan terima kasih kepada seluruh siswa dan guru SD Swasta HKBP II Pajak Baru Belawan dalam membantu mensukseskan kegiatan pengabdian masyarakat Universitas Sumatera Utara. 


\section{R E F E R E N C E}

Allegranzi, B. and D. Pittet. 2009. "Role of Hand Hygiene in Healthcare-Associated Infection Prevention." Journal of Hospital Infection.

A. Bianchi, D. M, (2009). WHO Guidelines on Hand Hygiene in Helath Care: a Summary. World Health Organization Patient Safety: University of Geneva Hospitals

A. E. Aiello, R. B. Coulborn, V. Perez, and E. L. Larson, (2008). Effect on Hand Hygiene on Infectious Disease Risk in the Community Setting: A-MetaAnalysis, in American Journal of Public Health, 98(8), 1372-1381

Ambarwati, Eny Retna and Prihastuti. 2019. “Gerakan Masyarakat Hidup Sehat (Germas) Mencuci Tangan Menggunakan Sabun Dan Air Mengalir Sebagai Upaya Untuk Menerapkan Perilaku Hidup Bersih Dan Sehat (Phbs) Sejak Dini." Celebes Abdimas: Jurnal Pengabdian Kepada Masyarakat.

Arsianti, Rika Wahyuni, Rian Kurniawan, Fairul, Mulyadi, Ana Damayanti, and Sulistia Rini Pratiwi. 2020. "Penerapan Alat Pencuci Tangan Dengan Kran Air Otomatis Sebagai Protokol Kesehatan Pada UMKM Kenko." ARSY : Aplikasi Riset Kepada Masyarakat.

D. Pittlet, (2009). WHO Guidelines on Hand Hygiene in Helath Care: a Summary. World Health Organization Patient Safety: University of Geneva Hospitals

Fitriyah H., Rosana Widasari E., Setiawan Eko, Angga Kusuma B., Interaction design of automatic faucet for standard hand-wash, MATEC Web of Conferences 154, 03003 (2018)

J. M. Boyce and D. Pittet, (2002). Guideline for Hand Hygiene in Health-Care Settings: Recommendations of the Healthcare Infection Control Practies Advisory Comitte and the HICPAC/SHEA/APIC/IDSA Hand Hygiene Task Force. Department of Health and Human Services: Morbidity and Mortality Weekly Report, USA

Kristyawati, Desy and Ilham Nurcahyo. 2015. "Perancangan Alat Pencuci Dan Pengering Tangan Otomatis Menggunakan Mikrokontroller Atmega16 Dan Scrolling Text Message Displa.” Jurnal Teknik Ftup.

M. Burton, E. Cobb, P. Donachie, G. Judah, V. Curtis and W. P. Schmidt, (2011). The Effect of Handwashing with Water or Soap on Bacterial Contamination of hands, In International Journal of Environmental Research and Public Health, 8(1), 97-1 